\title{
A Study on Consumer Satisfaction Towards E-Learning Apps with Special Reference to Madurai City
}

\author{
OPEN ACCESS \\ Manuscript ID: \\ Margaret Divya \\ Associate Professor, Department of Commerce \\ Lady Doak College, Madurai, Tamil Nadu, India \\ https://orcid.org/0000-0001-9675-9238
}

COM-2020-08043335

Volume: 8

Issue: 4

Month: October

Year: 2020

E-ISSN: 2582-6190

Received: 10.07.2020

Accepted: 25.08.2020

Published: 01.10.2020

Citation:

Divya, Margaret, and Vijayapriya. "A Study on Consumer Satisfaction Towards E-Learning Apps with Special Reference to Madurai City." ComFin Research, vol. 8, no. 4, 2020, pp. 51-55.

DOI:

https://doi.org/10.34293/ commerce.v8i4.3335

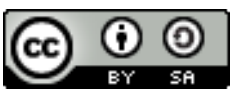

This work is licensed under a Creative Commons Attribution-ShareAlike 4.0 International License

\section{Vijayapriya}

Department of Commerce, Lady Doak College, Madurai, Tamil Nadu, India

\begin{abstract}
There are many terms used to describe learning that is delivered via the internet. E-learning or Electronic Learning is the portage of learning and training through digital resources like computers, tablets, laptops and, even cellular phones that are connected to the internet to access educational curriculum outside of a traditional classroom. This learning environment uses Information and Communication Technologies (ICT's) as a platform for teaching and learning activities. As this teaching and learning pedagogy earns high momentum amidst teaching and student community, the researchers belonging to the respective communities undertook this study with the sole purpose of finding out the effect of e-learning apps in this high technology invaded the digital world with X-Generation learners. This study is descriptive and analytical. This research paper focuses on customer awareness, preference, and the level of satisfaction towards eLearning apps. The researcher has formulated core objectives relevant to the study and, both primary and secondary data are collected from the customers belonging to Madurai City. This study has well defined the number of e-Learning apps to fulfill the objectives of the study with the help of the statistical techniques. The researcher has used the IBM SPSS statistics tool for data analysis and interpretation. The study reveals the fact that despite the majority of the respondents supporting e-learning methodology but there are a handful of respondents who strongly believe that e-learning cannot replace face-to-face teaching and a tight bond between a teacher and a student.
\end{abstract}

Keywords: E-Learning, IBM SPSS Statistics, Traditional Classroom, Digital Resources, Awareness and Moodle

\section{Introduction}

E-learning is a computer-based educational tool or system that enables us to learn anywhere and at any time. E-learning provides training or educational courses with the help of some electronics equipment such as a) a computer or a mobile computing device like a notebook, a tab, or smart mobile phone, b) some multimedia support equipment in the form of the mike, speakers, video camera, LCD projectors, CDROMs/DVDs, touch screens, light pens, smart boards, video-conferencing, etc., Honorable Prime Minister., Mr. Narendra Modi's government implemented some schemes like SWAYAM (Study webs of Active- learning for young aspiring minds): Under this program, professors of centrally funded institutions like IITs, IIMs will offer online courses to citizens of our country. The content can be easily accessed by students, working professionals, and researchers across the country through laptops, smart phone, and tablets. E-learning offers an alternative that is faster, cheaper, and potentially better. 


\section{Statement of the Problem}

There are several trends impacting the increased use of E-Learning. The ever-increasing global pressure to conform to the fast-paced changes in electronic communications today constantly renders current practices essential in a few years. So the researchers are interested in knowing about the customer awareness and preference towards e-learning applications and knowing about their level of satisfaction among e-learning apps.

\section{Scope of the Study}

Despite affirmative steps taken by the government in the form of national programs on technology-enhanced learning, national mission on education, national knowledge network, the gap between demand and supply in higher education is still high. So the researchers have taken only popular and significant apps for conducting the survey. The study is confined to the customers who use e-learning apps like BYJU'S, linked in learning, English-Tamil dictionary, the Hindu app, Dailyhunt (Newshunt), Kindle, Wikipedia (Encyclopedia), TED, TNPSC Tamil, Vision IAS, U-Dictionary, MOODLE, Office automation apps, Multimedia apps, National Geographic, BBC News service, English dictionarythesaurus, Oxford Dictionary of English, and Bible.

\section{Objectives}

1. To locate the meaning of e-learning.

2. To find out customer awareness of e-learning apps.

3. To know the customer preference towards e-learning apps.

4. To evaluate the level of satisfaction towards e-learning apps.

\section{Methodology}

This study is descriptive and analytical.

Sources of Data: The study is based on both primary and secondary data.

Primary Data: Primary data is the information collected directly from the respondents. It is first-hand information. Primary data is collected from customers who use e-learning apps through structured questionnaires.
Secondary Data: Secondary data are data that have already been collected by someone. Secondary data is composed of experiments or surveys, books, journals, websites, and newspapers.

Sampling Design: The population of the study is e-learning apps users. A simple random sampling technique is used.

Sample Size: The size of the sample for the study is 100 respondents.

Geographical Area of the Study: The vicinity of the study is limited to Madurai city only.

Period of the Study: The period of the study is 2019-2020

\section{Limitations}

1. The study is confined only to Madurai city.

2. The opinion and satisfaction level of E-learning app usage does not remain the same in the minds of consumers for a long duration.

3. E-learning depends on technology because not all people have stable internet access and computers that are powerful enough to support online streaming.

\section{Analysis and Interpretation \\ Demographic Profile of the Respondents}

The study implies that $34 \%$ of the respondents belong to $18-21$ years. In the gender-wise classification of the respondents, $73 \%$ of the people were female, and $27 \%$ of the people were male, and $56 \%$ of the people who do not earn income were using E-Learning applications. It was found that the respondents of $18-21$ years of age group and the female respondents were mostly using E-Learning applications. In the educational qualification, $34 \%$ of the respondents were undergraduate. In the occupation-wise classification, $59 \%$ of the respondents are students, and it was observed that $74 \%$ of the respondents are unmarried, and $26 \%$ of the respondents are married. It was concluded that most of the respondents are undergraduate students, and unmarried were using E-Learning applications compared to others. 
Awareness of e-Learning apps

The study clearly states that $78 \%$ of the respondents have Multimedia apps, and $51 \%$ of the respondents have Games, and $82 \%$ of the respondents do not have Translators, and $70 \%$ of the respondents do not have Learning apps.

\section{e-Learning Apps that are Aware of Downloaded and Used}

The study reveals that $60 \%$ of the respondents are aware of The Hindu app, TNPSC Tamil app and $59 \%$ of the respondents are aware of BYJU'S app, $58 \%$ of the respondents are aware of English - Tamil Dictionary, Wikipedia (Encyclopedia), TED, Linked in learning, National geographic channel,51\% of the respondents have downloaded English - Tamil Dictionary app, $32 \%$ of the respondents have downloaded, and Dailyhunt (Newshunt), 31\% of the respondents have downloaded Oxford Dictionary of English, $51 \%$ of the respondents have used the English - Tamil Dictionary app and 30\% of the people have used the Oxford Dictionary of English, and $29 \%$ of the respondents have used Dailyhunt (Newshunt).

\section{Concept Regarding the usage of e-Learning Apps}

From the study, it is understood that $2.64 \%$ of the respondents often use E-Learning applications, and $2.58 \%$ of the respondents think that E-Learning is costlier than classroom learning. Also, they suppose that Classroom learning is more expensive than E-learning.

\section{Opinion of e-Learning Apps from the Customer's Perspective}

About the opinion of e-learning apps from the customers, it shows that $4.24 \%$ (Mean Score) of the people like the idea of E-learning apps, $4.13 \%$ (Mean Score) of the respondents are identified that it is necessary to have high-quality E-learning apps, and $4.04 \%$ (Mean Score) of the respondents think E-learning is an innovative concept and must be encouraged.

\section{Preference of e-Learning Apps has been Given by the Respondents from One to the Sixth Rank}

From the study, it is understood that learners can learn in their leisure time and convenient place ranks first with Garrett mean score of 60.64 among the respondents, and E-Learning can save costs and time ranks second with Garrett mean score of 55.87 among the respondents.

\section{Significance of E-Learning Apps}

The study reveals that in the significance of E-learning apps from the customer's perspective shows E-Learning should be offered fully online to teach students living in a remote area is $4.30 \%$ (Mean Score), and E-Learning should be adopted to allow working students to study from office is $4.17 \%$,(Mean Score) E-Learning increases the quality of teaching $\&$ learning because it integrates all forms of media: Print, Audio, Video, Animation is $4.08 \%$.

\section{Satisfaction towards e-Learning Apps}

The study reveals that $4.31 \%$ (Mean Score) of the respondents think that E-Learning is useful for learning/teaching, $4.09 \%$ (Mean Score) of the respondents are compatible with general browsers on familiar hardware such as PCs, mobile devices, tablets, etc. and $4.15 \%$ (Mean Score) of the people are satisfied that Distance education (E-Learning) is worth the time.

\section{Limitations towards e-Learning Apps}

The data shows that $4.09 \%$ (Mean Score) of the respondents believe that E-Learning experiences cannot be equated with face-to-face learning, 3.99\% (Mean Score) of the respondents think that lack of constant net high connection and charges for the services.

\section{Suggestions}

The classroom environment will help the student to grow in all ways, and this is a great opportunity for those who should keep the education continue and make knowledge which gains from the classroom environment.

Support for offline content is must-have for E-learning apps. This feature allows the users to download the course content and access it at their convenience. So, the learners won't have to worry about connectivity issues, slow loading, and excessive battery consumption, which helps them focus on what really matters-learning. 
Online education is a good platform for the people who are not able to complete their studies, which they had left due to any reason. So due to that, they can be easily able to get a good position in a job. E-learning is also providing an opportunity for selflearners virtually.

E-learning is easy to capture at any time, anywhere, and they can learn their desired subjects through online education with stable internet access. Moreover, this also allows students to organize their time more effectively.

Without the physical presence of the teacher, learners can't learn properly. And also, learners wanted to accept all the foreign learning styles like E-learning apps.

E-learning will help the student to learn completely by giving more timely knowledge.

Learners can decide their speed of learning from the E-learning instead of following the velocity of the whole group from the classroom learning.

\section{Research Gap}

About the current study, there is a scope in learning other related concepts of e-learning apps such as

Impact of e-learning apps in Government Schools and its outcomes

Comparative study between e-learning apps and students academic performance

The growth trend of techno-savvy apps in modern times among the student and teaching community nation wide

\section{Conclusion}

E-learning is not just a change in technology. It has brought a positive impact on the lives of students and working professionals. So it is a redefinition of transmitting knowledge, skills, and values to younger generations of workers and students. In the era of digitalization, the scope of E-learning increases even more and will be beneficial for students, professionals, and also institutions. So this study shows that the level of satisfaction on the usage of E-learning apps among consumers.

\section{References}

Alonso, Fernando, et al. "An Instructional Model for Web Based E-Learning Education with a Blended Learning Process Approach.” British Journal of Educational Technology, vol. 36, no. 2, 2005, pp. 217-235.

Arkorful, Valentina, and Nelly Abaidoo. "The Role of e-learning, the Advantages and Disadvantages of its Adoption in Higher Education." International Journal of Education and Research, vol. 2, no. 12, 2014, pp. 397-410.

Arthur, Winfred, et al. "Effectiveness of Training in Organizations: A Meta-Analysis of Design and Evaluation Features." Journal of Applied Psychology, vol. 88, no. 2, 2003, pp. 234-245.

Clover, Isabelle. "Advantages And Disadvantages of eLearning." elearning Industry, 2017, https:// elearningindustry.com/advantages-anddisadvantages-of-elearning

Davis, Hugh C., and Karen Fill. "Embedding Blended Learning in a University's Teaching Culture: Experiences and Reflections." British Journal of Educational Technology, vol. 38, no. 5, 2007, pp. 817-828.

"Definition of E-learning." The Economic Times, https://economictimes.indiatimes.com/ definition/e\%20learning

E-Learning: Concepts, Trends, Applications, Epignosis LLC, 2014.

El-Seoud, Samir Abou, et al. "E-Learning and Students' Motivation: A Research Study on the Effect of E-Learning on Higher Education." International Journal of Emerging Technologies in Learning, vol. 9, no. 4, 2014, pp. 20-26.

Fearon, Colm, et al. "Value of Blended Learning in University and the Workplace: Some Experiences of University Students." Industrial and Commercial Training, vol. 43, no. 7, 2011, pp. 446-450.

Gillett-Swan, Jenna. "The Challenges of Online Learning Supporting and Engaging the Isolated Learner." Journal of Learning Design, vol. 10, no. 1, 2017, pp. 20-30.

Goel, Anubha. "Different Types of e-Learning and What Suits Me Best." GC-Solutions, http:// 
www.gc-solutions.net/resources/articles/ different-types-of-e-learning-and-what-suitsme-best.html

Graham, Charles R. "Blended Learning Systems, Definition, Current Trends and Future Directions." The Handbook of Blended Learning: Global Perspectives, Local Designs, John Wiley and Sons, 2005, pp. 3-21.

Grasha, Anthony F. "Teaching with Style: A Practical Guide to Enhancing Learning by Understanding Teaching and Learning Styles." Alliance Publishers, 1996.

Kanuka, Heather. "Understanding E-Learning Technologies-in-Practice through Philosophies-in-Practice." Theory and Practice of Online Learning, edited by T. Anderson, and F. Elloumi, 2008, pp. 91-118.

Macdonald, Iain S., et al. "Identifying Effective Pedagogical Approaches for Online Workplace Training: A Case Study of the South African Wood Products Manufacturing Sector." International Review of Research in Open and Distributed Learning, vol. 8, no. 3, 2007.

Masrom, Maslin. "Technology Acceptance Model and E-learning." $12^{\text {th }}$ International Conference on Education, Sultan Hassanal Bolkiah Institute of Education, 2007.
Parmar, Bhavik, et al. A Customer Preference and Perception towards Online Education in Ahmedabad city, Kadai Sarva Vishwavidyalaya University, 2018.

Poon, Joanna. "Use of Blended Learning to Enhance the Student Learning Experience and Engagement in Property Education." Property Management, vol. 30, no. 2, 2012, pp.129-156.

Sood, Manu, and Virender Singh. "E-Learning: Usage among Indian Students." International Journal of Scientific \& Engineering Research, vol. 5, no. 4, 2014, pp. 1353-1360.

"The Advantages and Importance of Online Learning." Entrepreneurship Campus, 2017, https://www.entrepreneurship-campus.org/ the-advantages-and-importance-of-onlinelearning

Trasler, John. "Effective Learning Depends on the Blend." Industrial and Commercial Training, vol. 34, no. 5, 2002, pp. 191-195.

Tsai, Chia-Wen. "Research Papers in Online Learning Performance and Behaviour." International Review of Research in Open and Distribution Learning, vol. 17, no. 1, 2016.

"What is eLearning?" eLearningNC, www. elearningnc.gov/about_elearning/what_is elearning

https://nipccd-elearning.wcd.nic.in/

\section{Author Details}

Dr. Margaret Divya, Associate Professor, Department of Commerce, Lady Doak College, Madurai, Tamil Nadu, India, Email ID: mdmdivya982@gmail.com

Ms. Vijayapriya, Department of Commerce, Lady Doak College, Madurai, Tamil Nadu, India,

Email ID: 18pgce28@ldc.edu.in 